1959

\title{
Privileged Communications between Physician and Patient
}

Clinton DeWitt

Follow this and additional works at: https://scholarlycommons.law.case.edu/caselrev

Part of the Law Commons

\section{Recommended Citation}

Clinton DeWitt, Privileged Communications between Physician and Patient, 10 Wes. Rsrv. L. Rev. 488 (1959)

Available at: https://scholarlycommons.law.case.edu/caselrev/vol10/iss4/5

This Article is brought to you for free and open access by the Student Journals at Case Western Reserve University School of Law Scholarly Commons. It has been accepted for inclusion in Case Western Reserve Law Review by an authorized administrator of Case Western Reserve University School of Law Scholarly Commons. 


\title{
Privileged Communications Between Physician and Patient ${ }^{1}$
}

\author{
Clinton DeWitt
}

$I_{1}$

N ANCIENT times, wholesale exclusion of classes of persons from the opportunity of testifying was the rule. A person might be disqualified to be a witness because of race, color, sex, infancy, condition of servitude, religion, relationship, interest in the outcome of the litigation, mental illness, or conviction of crime. ${ }^{2}$ In later years, as the common law developed, much, though not all, of the policy of exclusion was incorporated into the expanding rules of evidence. The courts considered this necessary in order to bar persons believed to be

THE AUTHOR (A.B., 1910, Western Reserve, LI.B., 1912, Western Reserve, LL.D., 1954, Temple) is Professor of Law Emeritus, Western Reserve University. biased, unstable, or untrustworthy from appearing as witnesses in a court of justice. At the beginning of the nineteenth century, most of the rules of exclusion were well established, but with a resulting loss of a vast amount of relevant evidence which might have aided the court, or the jury, in the final determination of the factual matters in dispute; moreover, the policy of exclusion had progressed so far that it had almost reached the realm of absurdity. With the passage of time, however, most of the grounds of absolute incompetency were swept away, the courts laying more emphasis upon the credibility of the witness; less upon his competency.

In England, for nearly four hundred years, compulsion of witnesses to appear and to testify has been the rule. Prior to that time, a person, if he could qualify as a witness, might testify or not as he chose; he could not be compelled to do so. In 1562, by Act of Eliz. c. 9, § 12, provision was made for the service of process out of any court of record requiring the person served to appear and to testify concerning any

1. The material herein has been extracted from sections $1,8,9$ and 11 of Professor DeWitt's latest book, PRIvileged COMMUNICAItons Between Physician AND PATIENT, published in 1958 by Charles C. Thomas who has graciously consented to the publication of this material. The Editors would also like to indicate that space limitations necessitated the deletion of many of the exhaustive footnotes found in the original text.

2. Barnhart, Theory of Testimonial Competency and Privilege, 4 ARK. L. REV. 377 (1950); Rowley, The Competency of Witnesses, 24 lowA L. REv. 482 (1939). 
cause or matter pending in the court, under penalty of ten pounds besides damages to be recovered by the aggrieved. This was based on the fundamental principle of government that the administration of justice is a murual benefit to all members of a community, and every competent citizen is under an obligation to further it as a matter of public duty; that the personal sacrifice is a part of the necessary contribution to the welfare of the public. ${ }^{3}$

Shortly after the policy of testimonial compulsion became established in England, the courts occasionally were confronted by witnesses who refused to answer particular questions put to them on the ground that their testimony would necessarily result in the disclosure of confidential communications or information which, for reasons of public policy or personal honor, they ought not to be compelled to reveal. Usually it was claimed by such witnesses that matters of a genuinely confidential character were not the proper subject of inquiry in courts of law; that, to improve the administration of justice, all persons should be encouraged to come forward with their evidence by shielding them as far as possible from compulsory disclosure of matters strictly confidential. On the other hand, it was urged that the courts were duty bound to see that complete justice was done; that to achieve this objective, no barrier should be erected against the discovery of the truth; that, therefore, no witnesses should have the right to withhold relevant evidence and thus suppress or conceal the truth, or any portion thereof, no matter how harmful to himself or to orhers its effect might be, ${ }^{4}$ provided it did not tend to convict him of a crime, or subject him to a penalty.

Ultimately, however, the courts became persuaded that the duty of testifying, so onerous at times yet so necessary to the administration of justice, should properly be subject to mitigation in exceptional circumstances. Accordingly, throughout the course of its history, the common law, both in British and American jurisdictions, has conferred ever-increasing privileges of non-disclosure in favor of particular persons who have been lawfully summoned to attend and to give evidence in the courts of justice, ${ }^{5}$ privileges which enable them to decline to answer questions which elicit the disclosure of confidential communications and informa-

3. Blair v. United States, 250 U.S. 273, 281 (1918); In re Herrnstein, 20 Ohio Op. 405, 412 (1941); Ealy v. Shetler Ice Cream Co., 108 W. Va. 184, 150 S.E. 539 (1929).

4. Learned Hand, J., in McMann v. Sec. \& Exch. Comm'n 87 F.2d 377, 378 (1937), cert. denied, 301 U.S. 684: ". . . the duty to disclose in a court all information within one's control, testimonially or by the production of documents, is usually paramount over any private interest that may be affected."

5. As to the basis of privileges, see 8 WIGMORE, EvIDENCE $\ S 2192,2197,2285$ (3d ed. 1940). 
tion inimical to the interest of the witness, ${ }^{6}$ or of the state, or of society in general. Broadly speaking, the matters affected by the doctrine of privilege may be classified as political, judicial, social, and professional. The more widely-known of these privileges are those which relate to state secrets, political votes, trade secrets, religious beliefs, anti-marital facts, and self-incriminating matters; those which have been extended to persons standing in a confidential relationship such as husband and wife, grand jurors, petit jurors, judges, arbitrators, public officers, and informers who furnish government officials evidence of crime; and that which is granted to attorneys acting in a professional capacity.

In justification of these privileges, it has been said that all of these matters lie in the policy of the state which considers that the injury to such relationships which would result from enforced disclosure of confidential information acquired therein, would be greater than the loss to justice occasioned by granting the privilege. ${ }^{7}$

\section{Medical Ethics aNd the LAW: The DUty of SeCRECY}

Everywhere medical confidences are regarded as sacred and precious. Unquestionably one of the highest duties of the physician is to keep secret and inviolate the intimate knowledge of his patient's disease, ailment, or physical imperfection, especially that which he learned by means of communication, observation, or examination in the course of his professional employment. Hippocrates (circa 400 B.C.), renowned as the "Father of Medicine," was perhaps the first to express the ethical duty of the physician. His Oath, a self-imposed criterion of professional conduct, has come down through the ages. Pledging himself that never would he voluntarily divulge the medical confidences of his patients, Hippocrates vowed, among other things:

Whatsoever things I see or hear concerning the life of men, in my attendance on the sick or even apart therefrom which ought not to be

6. It does not necessarily follow, however, that because a communication is made in confidence or upon a promise of secrecy, it comes under the protection of privilege. 8 WIGMORE, EVIDENCE $\$ 2286$ (3d ed. 1940); 5 JONES, COMMENTARIES ON Evidence $\ 2219$ (2d ed. 1926). See McMann v. Sec. \& Exch. Comm'n, 87 F.2d 377 (1937); In re Frye, 155 Ohio St. 345, 98 N.E.2d 798 (1951).

7. This view, however, has not been universally approved; in fact, there has been at times, strong opposition to the whole policy of testimonial privilege. See Purrington, An Abused Privilege, 6 ColuM. L. Rev. 388 (1906). And also see, Whipple, The Legal Privilege of Concealing the Truth, 10 MAss. L. Q. 31 (1925).

There is eminent authority for the view that the traditional justifications for various testimonial privileges are inept and fallacious. Morgan, Foreword, MODEL CODE OF EVIDENCE 22-30 (1942). McCormick, The Scope of Privilege in the Law of Evidence, 16 TExas L. REV. 447 (1938). 
noised abroad, I will keep silence thereon, counting such things to be as sacred secrets.8

Protected by no greater guaranty of secrecy than this, countless generations of men and women, freely and confidently, have entrusted their most intimate and delicate secrets to their medical advisers.

It must be remembered, however, that we are not dealing with a question of medical ethics or professional etiquette pertaining to the conduct of the physician outside the courtroom; on the contrary, we are concerned only with a testimonial privilege, created by legislative enactment, which prohibits a disclosure by the physician, when called to testify in a lawful proceeding, of confidential communications made to, or information acquired by, him in the course of his professional attendance upon the patient. It is manifest, of course, that a voluntary disclosure by the physician of medical confidences gained while attending the patient when not made in the course of his professional duty - is a plain violation of medical ethics and professional propriety, but the physicianpatient privilege statute does not prescribe a rule of conduct for the government of physicians in their general intercourse with society. Therefore, if the physician, disregarding the ethical duty of secrecy, should, in conversation or otherwise, reveal the intimate confidences of the patient, he would not violate the statute however reprehensible his conduct would be. ${ }^{9}$ As far as the statute goes, the physician may talk about the ailments of the patient from New York to San Francisco and to every Tom, Dick and Harry on the street or in his club, since the statute merely permits the patient, or the holder of the privilege, to seal the lips of the physician against testifying in a judicial proceeding, ${ }^{10}$ or

8. See Foxe, The Oath of Hippocrates, 19 PsXchIATRIC Q. 17 (1945); Brandeis, The Pbysician and Medical Etbics, 38 MED. REV. OF REv. 699 (1932); Flannagan, The Spirit of the Oath, 57 VA. MED. MO. 538 (1930).

For scope and effect of the oath, see Morrison v. Malmquist, 62 So.2d 415 (Fla. 1953).

9. Nelson v. Nederland Life Ins. Co., 110 Iowa 600, 81 N.W. 807 (1900); Simonsen ₹. Swenson, 104 Neb. 224, 177 N.W. 831 (1920); Buffalo Loan, Trust and Safe Dep. Co. v. Knights Templar and M. A. Ass'n, 126 N.Y. 450, 27 N.E. 942 (1891); Boyle v. Northwestern Mut. Relief Ass'n, 95 Wis. 312, 70 N.W. 351 (1897).

See DeWitt, Medical Etbics and the Law: The Conflict Between Dual Allegiances, 5 WEST. RES. I. REV. 5 (1953); Chafee, Is Justice Served or Obstructed by Closing the Doctor's Mouth on the Witness Stand? 52 YALE L. J. 607 (1943); Purrington, An Abused Privilege, 6 CoLUM. L. REv. 388 (1906). There is no punishment provided for the physician who reveals what has been confided to him. Jacobs v. Cedar Rapids, 181 lowa 407, 164 N.W. 891 (1917).

10. Noble v. United Benefit Iife Ins. Co., 230 Iowa 471, 297 N.W. 881 (1941). 
an investigation authorized by $1 \mathrm{aw},{ }^{11}$ and is wholly ineffectual to prevent a public disclosure elsewhere. ${ }^{12}$

\section{REASONS FOR THE STATUTE}

There has been and is a considerable difference of opinion regarding the purpose and policy of the statute. Various reasons for its enactment have been offered. It will be remembered that the common law afforded no protection whatever for the confidences reposed by sick and injured persons in their physicians. No matter what the confidence or secret was, however intimate or delicate, he who held it was compellable to disclose it in the interests of justice. Yet many persons, especially those of the medical profession, firmly believed that the fact that the physician was bound to reveal to the world in open court, whenever so directed by the judge, every bit of information he had acquired during his professional employment, could not but act as a deterrent so as to cause patients to suffer untold anguish and torment, rather than divulge facts inexorably held secret. That dread, whether the fear of exposure and disgrace, or the recoil from the infliction of humiliation or grief on others, was the real mischief, it was said, which the common law did not prevent or abate. ${ }^{13}$ It is highly probable, therefore, that it was precisely this presumptive "mischief" that the authors of the early statutes sought to put an end to.

Generally speaking, however, the courts have not been content to base the origin of the statutory privilege upon this ground alone. On the contrary, other purposes and objectives have been attributed to it. Some courts have held that one of its principal objectives is a humane one, since it gives the patient "free conduct and free tongue" with his medical adviser to the end that the latter may have the information necessary to enable him to render as much aid as possible for the restoration of the patient's health and for relief from his pain and discomfort. ${ }^{14}$ Others have said that its primary purpose is to protect the patient's right to

11. New York City Council v. Goldwater, 284 N.Y. 296, 31 N.E.2d 31, (1940).

12. American Republic Life Ins. Co. v. Edenfield, 306 S.W.2d 321 (Ark. 1957); Maryland Cas. Co. v. Maloney, 119 Ark 434, 178 S.W. 387 (1915); Noble v. United Benefit Life Ins. Co., 230 Iowa 471, 297 N.W. 881 (1941); Jacobs v. Cedar Rapids, 181 Iowa 407, 164 N.W. 891 (1917); People v. Shurley, 131 Mich. 177, 91 N.W. 139 (1902); Cramer v. Hurt, 154 Mo. 112, 55 S.W. 258 (1900).

13. Barton, $J$., in National Mut. Life Ass'n v. Godrich, 10 Comm. L. R. (Australia) 1,19 (1909).

14. Travelers Ins. Co. v. Bergeron, 25 F.2d 680 (1928), cert. denied 278 U.S. 638; Hartley v. Calbreath, 127 Mo. App. 559, 106 S.W. 570 (1907); Arnold v. Maryville, 110 Mo. App. 254, 85 S.W. 107 (1905); Green v. Metropolitan Street Ry., 171 N.Y. 201, 63 N.E. 958 (1902). 
privacy. ${ }^{15}$ Several courts have expressed the novel view that the real purpose of the statute is to protect the patient from his own physician; that frequently the patient and his physician do not stand on equal terms and, therefore, the patient may easily be imposed upon by his own physician and induced to make admissions detrimental to his own interests. ${ }^{16}$ The Supreme Court of Ohio, in adopting this view, went on to say that this defensive feature of the statute is an important one. ${ }^{17}$ Another explanation given for the existence of the statute is that the employeepatient may be under the care of a "company doctor" and because of the relationship between employer and physician, the physician, consciously or unconsciously, is inclined to give testimony more favorable to the company which employs him than to the employee-patient whom he has treated. ${ }^{18}$ It has also been said that the purpose of the statute is to place the information obtained by the physician from his patient substantially upon the same footing with the information acquired by an attorney while acting professionally in his client's affair. ${ }^{10}$

The great majority of the courts, however, declare that the primary purpose of the statute, manifest above all others, is to evoke and encourage the utmost confidence between the patient and his physician and to preserve it inviolate, ${ }^{20}$ so that the patient will freely and frankly reveal to his physician all of the facts, circumstances, and symptoms of his malady or injury, or lay bare his body for examination, and thus enable his physician to make a correct diagnosis of his condition and treat him more safely and efficaciously. ${ }^{21}$ It seems to be taken for granted that the

15. Studabaker v. Faylor, 52 Ind. App. 171, 98 N.E. 318 (1912); Chaffee v. Kaufman, 113 Kan. 254, 214 Pac. 618 (1923); Culver v. Union Pac. R.R., 112 Neb. 441, 199 N.W. 794 (1924); Davis v. Supreme Lodge, K. of H., 165 N.Y. 159, 58 N.E. 891 (1900); Williams v. State, 65 Okla. Crim. 336, 86 P.2d 1015 (1939).

If this view be sound, one may well ask why the lawmakers have not enacted a statute which will protect his right to privacy outside the courtroom.

16. Mr. Justice Pitney put forth this view in Arizona \& New Mexico Ry. v. Clark, 235 U.S. 669 (1915).

It is submitted with respect, that this animadversion upon the medical profession is undeserved and grossly unfair. Moreover, it seems well-nigh unbelievable that any legislature would indulge such a low opinion of the medical profession and found upon it a repressive statute.

17. Baker v. Industrial Comm'n, 135 Ohio St. 491, 21 N.E.2d 593 (1939).

18. United States Fid. \& Guar. Co. v. Hood, 124 Miss. 548, 87 So. 115 (1920).

See also dissent in Booren v. McWilliams, 26 N.D. 558, 588, 145 N.W. 410, 418 (1914).

19. Pierson v. People, 79 N.Y. 424, 433 (1880); Edington v. Mut. Life Ins. Co., 5 Hun. (N.Y.) 1, 8 (1875).

20. The statutes of California, Colorado, Guam, Idaho, Montana, Oregon and Utah expressly declare this to be the policy of the privilege.

21. Miller, J., in Edington v. Mut. Life Ins. Co., 67 N.Y. 185, 194 (1876) : "To open the door to the disclosure of secrets revealed on the sick bed, or when consult- 
legislatures which enacted the statute firmly believed that this desirable objective could best be attained by prohibiting physicians to reveal in courts of law the medical confidences imparted to them, especially those pertaining to diseases or physical imperfections which might expose the patient to civil or criminal prosecution, or subject him to humiliation, embarrassment, disgrace, reproach or unfriendly comment. ${ }^{22}$

\section{Criticism of the Privilege}

The main purpose of a judicial inquiry is to ascertain by rational means where the truth lies upon the issue of fact involved; and the policy of the law is to require the disclosure of all information by witnesses in order that justice may prevail. The primary object of all the laws of evidence, therefore, should be to bring the whole truth of a case before the court and jury. No thoughtful person will deny that the exclusion of relevant and important evidence - oftentimes the best evidence - presents a serious obstacle to the administration of justice. For how otherwise can justice be done unless the judgment rests upon truth, and truth alone? It seems strange, therefore, that a system of law designed to ascertain the truth, should embody rules which permit a litigant to withhold or shut out, at his option, material portions of it. Hence, a statute which prevents a physician, when lawfully summoned as a witness, from testifying to facts within his personal knowledge and relevant and material to the issue on trial, can only be justified by clear and convincing proof, based on reason and experience - not on sentiment or surmise - that the claimed advantage and benefits which may result to the general public from the shielding of confidences arising from the physician-patient relationship, far outweigh the harm and injustice which necessarily results to litigants from the concealment or suppression of the truth in actions in which the public has little or no concern. ${ }^{23}$

ing a physician, would destroy confidence between the physician and the patient, and, it is very easy to see, might tend very much to prevent the advantages and benefits which flow from this confidential relationship."

22. City and County of San Francisco v. Superior Court, 37 Cal.2d 227, 232, 231 P.2d 26, 28 (1951): "The whole purpose of the privilege is to preclude the humiliation of the patient that might follow the disclosures of his ailments." Pierson v. People, 79 N.Y. 424, 434 (1880): "The plain purpose of this statute ... was to enable a patient to make known his condition to his physician without the danger of any disclosure by him which would annoy the feelings, damage the character, or impair the standing of the patient while living, or disgrace his memory when dead. It could have no other purpose."

For an exhaustive list of representative cases explaining the purpose and policy of the privilege see DeWITT, PRIVILEgEd COMMUNICATIONS BETWEEN PHYSICIAN AND PATIENT, \$9 n. 11 (1958).

23. Chafee, Is Justice Served or Obstructed by Closing the Doctor's Mouth on the Witness Stand? 52 YALE I. J. 607, 609 (1943): "Secrecy in court is prima facie 
Throughout its history, the physician-patient privilege has been the subject of considerable discussion and, admittedly, much has been said in its favor. Unquestionably, the legislatures which adopted the privilege deemed it a wise one ${ }^{24}$ and, as we have seen, many courts have justified its existence on the ground of public policy. But the public policy of one generation may not, under different conditions, be the public policy of another. "Things change, and times change, and men change." Experience, the most dependable of all teachers, has demonstrated that the hopes of the authors of the original statute were illusive. No thoughtful judge or trial lawyer will deny that the privilege, in our day, is much abused. The law reports, federal and state, and the accumulated experience of judges and lawyers in the trial courts furnish ample evidence of this fact. ${ }^{25}$ It is not surprising, therefore, that, in recent years, the voices of disapproval have become predominant. Judges, lawyers, textwriters, and teachers have severely criticized the privilege as having but little, if any, justification for its existence, ${ }^{26}$ and of effecting great injury to the cause of justice by the concealment and suppression of useful truth, ${ }^{27}$

calamitous, and it is permissible only when we are very sure that frankness will do more harm than good. With doctors' secrets as with any other kind of secrets, the only proper test is the welfare of the community. Courtroom secrecy in the particular case must produce a public good which more than offsets the risks resulting from the concealment of truth and from the lies which can be made with less fear of detection."

See also 8 WigMORE, Evidence $\$ 2285$ (3d ed. 1940).

24. The fact, however, that England, Scotland, and most of the other jurisdictions of the British Commonwealth of Nations, as well as seventeen American jurisdictions, have never adopted the privilege, clearly indicates that its wisdom has not been universally apparent.

25. Iamm, J., in Epstein v. Pennsylvania R.R., 250 Mo. 1, 40, 156 S.W. 699, 711 (1913): "The scandals in beating down the truth arising from a too harsh and literal interpretation of this law . . . every one of us knows by experience and observation in the courtroom."

See also Randa v. Bear, 312 P.2d 640 (1957).

26. Freedman, Medical Privilege, 32 CAN. B. Rev. 1, 4 (1954); Duque, Privileged Communications Between Physician and Patient, 360 INS. L. J. 19 (1953); Peterson, The Patient-Physician Privilege in Missouri, 20 KAN. L. REv. 122, 136 (1952); Barnhart, Theory of Testimonial Competency and Privilege, 4 ARK. L. RRv. 377, 406 (1950); Iipscomb, Privileged Communications Statute - Sword and Sbield, 16 MIss. I. J. 181 (1944); Morgan, Suggested Remedy of Obstructions to Expert Testimony by Rules of Evidence, 10 U. CHI. L. REv. 285, 290 (1943); Welch, Anotber Anomaly - The Patient's Privilege, 13 Miss. I. J. 137 (1941); Curd, Privileged Communications Between the Doctor and his Patient, 44 W. VA. L. Q. 165 (1938); 81 U. PA. L. REv. 755 (1933); Purrington, An Abused Privilege, 6 ColUM. I. RBV. 388 (1906); Purrington, A Recent Case of Patient's "Privilege," 9 BENCH AND BAR 48 (1907); Bach, The Medico-Legal Aspect of Privileged Communications, 10 MEDICO-LEG. J. 33 (1892).

See also 8 WIGMORE, EVIDENCE $\subseteq 2380$ a (3d ed. 1940). This is the best get most severe of all criticisms.

27. GreENLEAF, EVIDENCE $\ 247$ a (16th ed. 1899) : "In all these cases, the medi- 
the disclosure of which ordinarily could harm no one. ${ }^{28}$ In denouncing the privilege, some of these have characterized it as a "farce," "parody on justice," "misguided sentimentality," "sop," "instrument of injustice," "perversion of justice," "monumental hoax" and an "obstruction to the administration of justice." Wigmore has described it as "merely a clever legerdemain, loaned by the Law to the parties to suppress the truth,"29 and two judges have regarded it as one which may oftentimes "cheat" rather than promote justice. ${ }^{30}$

It has been estimated that ninety percent of the litigation in which the privilege is invoked consists of three classes of cases: (a) actions on policies of life, accident or health insurance; (b) actions for damages for personal injury or for wrongful death; (c) testamentary actions where the mental competency of the testator is the principal issue. In nearly all of the cases, the testimony of the physician who attended the patient is generally the best and most reliable evidence. Nevertheless and notwithstanding, the patient, or the holder of the privilege may, at his option, close the door of all courts to the receipt of the physician's testimony no matter how much light it may throw upon the controversy, no matter how much logical connection it may have with the issue of fact to be proved or disproved. ${ }^{31}$ In other words, as one court frankly stated, ${ }^{32}$ the statute permits the holder of the privilege to use the testimony of the physician if he thinks the evidence will bolster his case, or exclude it if offered by his adversary, when he thinks it will weaken it. The question of dealing justly between the patient, or the holder of the privilege, and third parties is a secondary consideration. ${ }^{33}$

cal testimony is 'the most vital and reliable,' 'the most important and decisive,' and is absolutely needed for the purpose of learning the truth."

28. Boyles v. Cora, 232 Iowa 822, 848, 6 N.W.2d 401, 414 (1942).

29. 8 WIGMORE, EvIDENCE $\ 2389$ (3d ed. 1940).

30. Start, C.J., in Olson v. The Court of Honor, 100 Minn. 117, 123, 110 N.W. 374,377 (1907); Owen, J., in Maine v. Maryland Cas. Co., 172 Wis. 350, 359, 178 N.W. $749,752(1920)$.

31. Travelers Ins. Co. v. Bergeron, 25 F.2d 680, 683 (1928), cert. denied, 278 U.S. 638: "In many cases it will close the door to the best possible evidence on the issue of fact presented for determination." Renihan v. Dennin, 103 N.Y. 573, 9 N.E. 320 (1886); Paxos v. Jarka Co., 314 Pa. 148, 171 Atl. 468 (1934).

It is interesting and very welcome to note that the legislatures of some states have amended their statutes so as to withdraw the privilege from operation in one or more of these classes of cases.

32. Record v. Saratoga Springs, 46 Hun. (N.Y.) 448 (1887), aff'd, 120 N.Y. 646, 24 N.E. 1102 (1890).

33. Arizona \& New Mexico Ry. v. Clark, 235 U.S. 669 (1915); American Bankers' Ins. Co. v. Hopkins, 67 Okla. 150, 169 Pac. 489 (1917).

Some courts have lamented the fact that the privilege gives aid and comfort to unscrupulous litigants in many cases with the result that innocent persons are mulcted of large sums of money; nevertheless "with face unmoved" and aware of the wrongs 
The principal reasons advanced in support of the privilege are not convincing. The traditional theory that a person suffering from a serious disease or painful injury will hesitate to confide in a physician unless he has complete assurance that his confidences cannot later be revealed by the physician ${ }^{34}$ in some future litigation, has been thoroughly discredited and disproved. The basic fallacy of the theory is that one must assume that the prospective patient knows all about the privilege and, specifically, the protection it affords. Of course, such an assumption is utterly unwarranted. There is not one patient in many thousands who knows anything about the privilege or has ever heard of it. It need not be remarked that unless the patient has some knowledge of the protection afforded by the privilege before he consults the physician, there can be no reliance upon it; therefore, it can have no effect whatever upon the patient's state of mind and can offer no inducement to him to freely and frankly reveal confidential information which he would not otherwise disclose. ${ }^{35}$ Furthermore, only a relatively small number of patients would shy at consulting a physician even though they knew that he might later be required to disclose their state of health or the nature and effect of their injuries in a court of law. It need hardly be mentioned that as compared with the numerous ailments which affect the human body, those which bring shame and disgrace to the sufferer are inconsiderable. Ordinarily, bodily injuries and disease are attended with neither humiliation nor disgrace and most of them are not kept secret even by the patients themselves, many of whom, if given the chance, being ready and willing to relate to their friends and relatives the details of their maladies, injuries, or surgical operations. In all the range of human ailments there is, perhaps, but one that the sufferer would be prone to conceal, and that is venereal disease. But even in the matter of this loathsome disease, the physician, in practically every state, is required by law to report such cases to the

being perpetrated, they have enforced the statute to the point of rank absurdity. See Meyer v. Supreme Lodge, K. of P., 178 N.Y. 63, 70 N.E. 111 (1904), aff'd, 198 U.S. 508 (1905).

34. The incongruity of the privilege is patent. If it be true that it is designed to encourage persons to consult freely their medical advisers, why, then, is it not extended to psychiatrists, nurses, Christian Science practitioners, and professional men engaged in specialized fields of medical science? Surely the secrets imparted to such persons engaged in the art of healing are often as intimate and sacred as those acquired by physicians engaged in the general practice of medicine.

35. Some courts have disapproved this view. People v. Stout, 3 Park. Cr. (N.Y.) 670,679 (1858): "It is no valid objection to an application of this statute, that the prisoner [the alleged patient] did not probably know of its existence, and had no opinion whether or not the particulars of that interview would be privileged from disclosure. It is a sufficient answer that the salutary rule of law stands upon the statute book, and is to be dispensed alike to those familiar with or ignorant of its existence and applicability." 
public health authorities where it may become a matter of public record. Nevertheless, experience has shown that even this fearsome but required publicity will not discourage patients from making a full disclosure of their symptoms and distress to their physicians.

Another and, perhaps, the most favored theory is that the injury to the relationship of physician and patient is greater than the injury to the cause of justice; that in the interests of the public health ${ }^{36}$ public policy demands that medical confidences be protected against disclosure. There is not a whit of evidence that the privilege tends to improve the public health. ${ }^{37}$ On the other hand, there is abundant evidence that it undermines the very foundations of justice. The conjectural social policy behind such privilege is completely overborne by the injustices which too often result from the suppression of relevant and important evidence. ${ }^{38}$ It need hardly be observed that the citizens of seventeen states in America and countless persons in the British Commonwealth of Nations freely consult their physicians with no assurance whatever that, should their state of health or their injuries become the subject of litigation, their confidences cannot be revealed by their physicians when relevant to the issues on trial; yet the level of public health in these jurisdictions has not, for lack of a physician-patient privilege, been lowered beyond that of other jurisdictions which have adopted it ${ }^{39}$ Furthermore, no one would contend that the progress of medical science in the great hospitals and medical schools in Baltimore, Boston, and Chicago, for example, has been retarded because their patients do not have the protection of the privilege. Patients attend these renowned institutions not to bring damage suits but to seek medical advice and treatment, and the lack of a physician-patient privilege does not deter a single one of them from disclosing to the physicians and surgeons their most intimate confidences or submitting their naked bodies for examination.

In the vast majority of the reported cases where the privilege has been claimed, the patient or the party objecting to the testimony of the attending physician, did not invoke the privilege in order to protect the patient's right to privacy or to prevent the disclosure of matters which would

36. Snyker v. Snyker, 245 Minn. 405, 407, 72 N.W.2d 357, 359 (1955); "This statutory shield is solely for the protection of the patient and is designed to promote health and not truth." See MCCORMICK, EvIDENCE $\$ 105$ (1954).

37. Morgan, Comments on the Proposed Code of Evidence, 20 CAN. B. REv. 271, 279 (1942); Ladd, A Modern Code of Evidence, 27 lowA L. REv. 213, 224-225 (1942); Morgan, Some Observations Concerning a Model Code of Evidence, 89 U. PA. L. REv. 145, 151 (1940).

38. Iarson, C.J., in Clawson v. Walgreen Drug Co., 108 Utah 577, 602, 162 P.2d 759, 771 (1945).

39. Morgan, Suggested Remedy of Obstructions to Expert Testimony By Rules of Evidence, 10 U. CHI. L. REv. 285, 291 (1943). 
humiliate or disgrace the patient; ${ }^{40}$ rather his primary motive was to use the privilege as a procedural device for the single purpose of winning a lawsuit by excluding relevant and material evidence which, were it admitted, would tend to reduce, if not defeat, his chances for a verdict in his favor. ${ }^{41}$ The accumulated experience of many decades shows that the privilege has accomplished little but the concealment and suppression of the truth. When a party voluntarily puts in issue his state of health or his bodily injury and discloses the details thereof to serve his own pecuniary ends, any good and sufficient reason for maintaining the silence of the physician no longer obtains. A patient may keep the door of the sick-room closed, but he should not be permitted to open it so as to give an imperfect or false view of what took place there, and promptly shut the door the moment the true facts are about to be revealed. It is a monstrous thing to permit a party to fabricate evidence for himself in this class of cases, and then deny his adversary the right to resort to the only reliable means to elict the truth. Nevertheless, the law reports are filled with cases where such miscarriages of justice have occurred. ${ }^{42}$

In the few instances where an honest patient does dread disclosure of his state of health by the physician, his real and most distressing fear is not that the physician may some day be compelled to disclose the truth in a court of law, but that he will voluntarily reveal the facts to some friend or relative on the street or in his club, or that the physician may make his affliction the subject of an article in some medical journal or of an address before a group of medical men. Yet the physician-patient privilege affords him no protection against this possible danger. ${ }^{43}$

40. Fowler, J., in Prudential Ins. Co. v. Kozlowski, 226 Wis. 641, 644, 276 N.W. 300,302 (1938).

41. Purrington, $A$ Recent Case of Patient's Privilege, 9 BENCH AND BAR 48, 52 (1907): "What is there indelicate or of a nature to humiliate a patient claiming damages for defective vision or a broken leg, or any other injury displayed in evidence, in proving that the condition attributed to a recent accident was of long standing? Such a disclosure might show that the litigation was dishonest; but the physician's testimony ... would not be in itself humiliating or disgraceful, or reveal any secret except that the injury exhibited as new was in fact old."

42. Some judges and text writers have unsparingly denounced the abuse of the privilege. Dahlquist v. Denver \& Rio G.R.R., 52 Utah 438, 454, 174 Pac. 833, 839 (1918); 8 WIGMORE, EVIDENCE $\ 2389$ (3d ed. 1940): "The privilege under those circumstances becomes a burlesque upon logic and justice." See Nelson v. Ackerman, 83 N.W.2d 500, 506 (Minn. 1957).

43. That this danger is not fanciful can be proved by several reported cases where physicians and hospitals made extra-judicial disclosures, or exhibitions of their patients' ailments or physical imperfections under circumstances constituting an unwarranted invasion of their rights to privacy. See Bazemore v. Savannah Hospital, 171 Ga. 257, 155 S.E. 194 (1930); DeMay v. Roberts, 46 Mich. 160, 9 N.W. 146 (1881); Sullings v. Shakespeare, 46 Mich. 408, 9 N.W. 451 (1881); Feeney v. Young, 191 App. Div. 501, 181 N.Y. Supp. 481 (1920); Griffin v. Medical Society, 11 N.Y.S.2d 109 (1939). 
But there are hopeful signs of better things to come. The mounting waves of protest are inexorably beating down the worn-out theories which hitherto have sustained the whole policy of testimonial privilege. The manifest destiny of the laws of evidence is a lowering of the barriers which have held back the truth. ${ }^{44}$ Perhaps the physician-patient privilege is on the way out. It is ironical indeed that much of the pressure operating against the privilege is being exerted by the very legislatures which enacted it. They have all but cancelled out the intended benefits of the statute. Most of the medical confidences they once saw fit to preserve inviolate are now required by them to be reported by physicians, and sometimes by hospitals, to the public health authorities and, on some occasions, to particular persons who are likely to come in contact with their patients; moreover, some of these reports are made a matter of public record. It should be noted also that not only is the physician required to report such information but, in many cases, he can be compelled to testify and relate the facts and his conclusions thereon. ${ }^{45}$ In most of the states, physicians are now required by law to prepare and file for public record certificates of death which state the causes of death and whether they are accidental, homicidal, or suicidal. In some states the legislatures have enacted laws which require drunken operators of automobiles to submit to blood, saliva, and urine tests; and some compel prostirutes to submit to physical examinations for venereal disease. In a number of states, the legislatures have authorized the courts to appoint physicians to examine and to testify on the mental condition of persons suspected of feeblemindedness or insanity, or of being sexual psychopaths; and there are many more such laws.

As a result of the astounding change in the attitude of the legislatures, there are today few medical confidences that can really be kept secret except, of course, in a court of law where justice cries out for the facts. But why, we ask, should they be protected there? Honest patients have little to fear for they will not hide the truth, whether the privilege exists or not. Except in rare cases, only the dishonest litigant will attempt to shut out truth. It is high time to abolish the physician-patient privilege.

44. McCormick, The Scope of Privilege in the Law of Evidence, 16 TEXAS L. REv. 447, 469 (1938). Judge Jerome Frank has recommended abolition of most of the exclusionary rules of evidence except those relating to self-incrimination and to evidence obtained by unlawful search and seizure. FRANK, COURTS ON TRIAL 422 (1949). See also De Parcq, The Uniform Rules of Evidence, 40 MINN. L. REv. 301, 322-327 (1956).

45. DeWitt, Medical Etbics and the Law: The Conflict Between Dual Allegiances, 5 WEST. RES. L. REV. S, 8 (1953). 